\title{
„NASZ DOM JUŻ NIE JEST TAKI SAM" - POCZUCIE OSAMOTNIENIA W RODZINIE OSIEROCONEJ
}

Przedmiotem podjętych badań byto osamotnienie $w$ rodzinie spowodowane śmiercia rodzica/matżonka wskutek dlugotrwatej choroby.

Badaniami jakościowymi objęto 10 rodzin (6 matek, 4 ojców, 15 dzieci) zamieszkujących w mieście Biatystok, będacych w okresie żałoby od dwóch lat. Wykorzystano metodę indywidualnego przypadku oraz techniki badawcze: wywiad skategoryzowany $i$ wywiad narracyjny.

Stowa kluczowe: samotność i osamotnienie, dom rodzinny, funkcjonowanie rodzin pograżonych $w$ żałobie

\section{Samotność i osamotnienie - wprowadzenie do problematyki}

Zdefiniowanie pojęcia osamotnienie jest trudne ze względu na mylne utożsamianie go i zamienne stosowanie z terminem samotność. Jego przyczyn, zdaniem B. Hołysta, poszukiwać należy w utracie bliskiej osoby lub zerwaniu z nią kontaktu, ale też długotrwałej samotności i braku satysfakcji z istniejących relacji społecznych ${ }^{1}$. Analizując wielorakie źródła i czynniki osamotnienia, badacze zagadnienia koncentrują uwagę w szczególności na: wczesnych doświadczeniach człowieka (teorie psychodynamiczne), sieci wzmocnień społecznych wpływających na jego zachowanie (teorie społecznego uczenia się), wartościach i normach kulturowych (teorie socjologiczne), różnych indywidualnych preferencjach i poglądach

* Joanna Szymanowska - dr, Uniwersytet w Białymstoku, Wydział Pedagogiki i Psychologii, Zakład Socjologii Edukacji i Gerontologii Społecznej. Obszar zainteresowań: pedagogika społeczna, praca socjalna.

1 B. Hołyst, Na granicy życia i śmierci, Warszawa 1997, s. 365. 
(teorie poznawcze) $)^{2}$. W interpretacji psychologów, psychiatrów, pedagogów czy socjologów zaburzenia zachowania i rozwoju człowieka są wynikiem zakłóceń funkcjonalno-strukturalnych oraz niewłaściwych relacji emocjonalnych w rodzinie. Istotą stanu osamotnienia dziecięcego jest zazwyczaj poczucie braku miłości, zrozumienia, opuszczenia, odrzucenia i akceptacji ${ }^{3}$. Odtrącenie emocjonalne, trwałe zerwanie bądź ograniczenie więzi pomiędzy dzieckiem a rodzicem powoduje pojawienie się cech znamiennych dla syndromu deprywacji, atrofii psychicznej, bezrodzinności, choroby sierocej, lęku separacyjnego, autoalienacji czy sieroctwa. Osamotnienie jest reakcją na brak ważnych społecznych wzmocnień ${ }^{4}$, wypełniają je takie przeżycia jak: gniew, pesymizm, niezaradnośćs.

Termin ,poczucie osamotnienia” oznacza nie tylko sytuację emocjonalną człowieka, ale też jego sytuację społeczną. Jak twierdzą E. Łuczak i K. Szewetowska, jest to stan lub sposób przeżywania rozbieżności pomiędzy wymaganiami stawianymi przez role społeczne a sądami o samym sobie ${ }^{6}$. Odmiennie eksplikuje pojęcie A. Szymborska, interpretując je w kategoriach przeżyć wyłącznie subiektywnych w przestrzeni dziecięcego świata i odzwierciedlających jego przeświadczenie o tym, ,że do nikogo nie należy” i „nikt nie należy do niego"7. P. Mellody do symptomów poczucia osamotnienia, zwłaszcza w rodzinie, zalicza natomiast trudności w odczuwaniu własnej wartości, wytyczaniu funkcjonalnych granic, doświadczeniu i wyrażaniu rzeczywistości oraz zaspokajaniu indywidualnych potrzeb i pragnień ${ }^{8}$. Osamotnienie występuje najczęściej jako reakcja na ograniczenie lub całkowitą niemożność kontaktu człowieka z osobami bliskimi, spowodowaną najczęściej ich fizyczną nieobecnością ${ }^{9}$ Różne są jego rodzaje w zależności od czasu trwania, stopnia intensywności, głębi przeżyć oraz ich zakresu i treści,

2 K. Kmiecik-Baran, Poczucie osamotnienia - charakterystyka zjawiska, „Przegląd Psychologiczny" 1988, t. XXXI, nr 4, s. 1086.

3 T. E. Olearczyk, Sieroctwo i osamotnienie. Pedagogiczne problemy kryzysu wspótczesnej rodziny, Kraków 2007, s. 96.

4 J. E. Young, Loneliness, depression and cognitive therapy: Theory and application, w: Loneliness: A sourcebook of current theory, research and therapy, red. L.A. Peplan, D. Perlman, New York 1982.

5 D. Perlman, L. A. Peplan, Toward a social psychology of loneliness, w: Personal relationships in disorder, red. W. Duck, R. Gilmour, London 1981.

6 E. Łuczak, K. Szewetowska, Rozmiary sieroctwa społecznego, „Problemy Opiekuńczo-Wychowawcze” 1997, nr 2.

7 A. Szymborska, Sieroctwo społeczne, Warszawa 1969, s. 67.

8 P. Mellody, Facing codependence. What it is, Where it comes from, how it sabotages our lives, San Francisco 1993, s. 21.

9 M. Łopatkowa, Samotność dziecka, Warszawa 1983, s. 23. 
a także źródeł je wywołujących ${ }^{10}$. Pogłębiona analiza problematyki osamotnienia dziecięcego w rodzinie osieroconej pozwala na wyszczególnienie jego wielorakich typów, m.in. częściowego (występującego w sytuacji braku jednego rodzica na skutek śmierci), wtórnego (powstałego w wyniku utraty osoby bliskiej), sytuacyjnego (jako konsekwencji odseparowania dziecka od osób bliskich z powodów od niego niezależnych), chronicznego (dotykającego dzieci po śmierci rodzica) oraz emocjonalnego (przejawiającego się osłabieniem więzi z jedną lub wieloma osobami, obniżającego poczucie własnej wartości dziecka, uniemożliwiającego odczuwanie sensu życia oraz bycia potrzebnym i kochanym ${ }^{11}$.

Powszechnie przyjmuje się tezę, że osamotnienie i samotność to problemy o charakterze społecznym dotyczącym zarówno populacji osób dorosłych, jak też dzieci. Rozróżnienia szczegółowego pomiędzy tymi stanami dokonuje Jan Szczepański. Analizując pierwszy z nich należy, zdaniem autora, skupić uwagę na człowieku, jego obcowaniu w obrębie własnego wewnętrznego świata. Interpretując zaś drugi - na braku kontaktu zarówno z innymi ludźmi, jak też z samym sobąa ${ }^{12}$. Osamotnienie może być rozpatrywane jako stan samotności psychicznej, nacechowany subiektywizmem i indywidualizmem ${ }^{13}$. Samotnością określa się natomiast ,nieprzyjemny stan psychiczny, będący wynikiem niezadowolenia z ilości i jakości społecznych i emocjonalnych związków jednostki z innymi ludźmi”'14. Nie jest ona kategoryzowana jako odczucie homogeniczne, może występować w różnych okolicznościach, okresach ontogenezy, z niejednorodnym nasileniem i w wielorakiej postaci. W sytuacji, gdy nie stanowi dobrowolnego wyboru, co jest znamienne zwłaszcza w przypadku dziecka - niesie ból, izolację, tęsknotę. Ten niezwykle pejoratywny wydźwięk samotności Maria Szyszkowska postrzega jako „samotność całkowitą, w krystalicznej postaci, odczuwaną jako brak akceptacji przez kogokolwiek, poczucie zupełnej bezużyteczności, wrażenie, że świat jest pustynią, a istnienie na nim wynikiem straszliwej pomyłki i kary. To szamotanie się w mrocznym labiryncie, z którego nie ma wyjścia, to rozpaczliwe wołanie o pomoc bez cienia nadziei na odzew, to poczucie zawieszenia w próżni" ${ }^{15}$. Najbardziej bolesną formą samotności są stany permanentnej oschłości i braku wzajemnej

10 J. Izdebska, Dziecko osamotnione w rodzinie. Kontekst pedagogiczny, Białystok 2004, s. 29.

11 Ibidem; E. Pawłowska, E. Jundziłł, Pedagogika człowieka samotnego, Gdańsk 2003.

12 J. Szczepański, Sprawy ludzkie, Warszawa 1978, s. 20-21.

13 J. Gajda, Samotność i kultura, Warszawa 1987, s. 40.

14 J. Rembowski, Samotność, Gdańsk 1992, s. 32.

15 M. Szyszkowska, Ucieczki w samotność i osamotnienia, w: Samotność i osamotnienie, red. M. Szyszkowska, Warszawa 1988, s. 40. 
komunikacji doświadczane wśród osób bliskich, rodzące w konsekwencji podstawowe mechanizmy obronne w postaci reagowania lękiem oraz agresją.

\section{Dom rodzinny w obliczu długotrwałej choroby i śmierci}

Rozumienie rodziny i domu rodzinnego jako pierwszego i niezastąpionego środowiska wychowawczego będącego podstawą transmisji wartości i zasad życia społecznego stanowi podstawowy przedmiot zainteresowań pedagogiki społecznej. $\mathrm{W}$ wychowaniu rodzinnym jest bowiem wyraźnie ugruntowana rola wszystkich członków rodziny, a szczególnie rodziców. Ich fundamentalnym posłannictwem jest uczenie dziecka wrażliwości na otaczający świat, wyrażanie dbałości o prawidłową atmosferę życia rodzinnego wyznaczoną wzajemną życzliwością, wsparciem, opieką, ale też poświęcanie mu swojego czasu, czytelne okazywanie uczuć, wspólne dążenie do wyznaczonych celów oraz wyrażanie troski o możliwość zaspokajania jego potrzeb. W tak interpretowanym domu rodzinnym może kształtować się właściwy rozwój psychiczny i fizyczny dziecka oparty na relacjach o charakterze emocjonalnym i rodzinnych działaniach opiekuńczo-zabezpieczających. Do podstawowych właściwości domu rodzinnego można zaliczyć: bliskość, intymność, poczucie bezpieczeństwa, otwartość, hierarchiczność, prywatność, zbiór znaczących przedmiotów, wyjątkową i niepowtarzalną w innych wspólnotach rodzinną więź emocjonalną ${ }^{16}$. Tak rozumiany dom jawi się jako miejsce spotkania, dialogu oraz transmisji wartości, kultury, tradycji.

Analiza dotychczasowych badań na temat domu rodzinnego ukazuje, iż zagadnienie to było przedmiotem zainteresowań niewielu badaczy. Zdecydowanie największy dorobek naukowym w tym zakresie obserwuje się głównie w obszarze pedagogiki społecznej, niemniej jednak i w tej subdyscyplinie pedagogicznej więcej uwagi poświęcano do tej pory problematyce rodziny, a nie stricte domowi rodzinnemu. W badaniach tych dominujący był głównie wpływ podejścia socjologicznego wskazujący na społeczny charakter rodziny, role, do których przygotowuje swoich członków, oraz funkcje pełnione wobec nich i szerszego otoczenia społecznego ${ }^{17}$. Rozważania psychologów w tym zakresie koncentrowały się głównie na analizie mechanizmów wewnętrznych związanych z funkcjonowaniem domu rodzinnego oraz jego znaczenia i wartości z perspektywy indywidualnej oraz z punktu widzenia środowiska rodzinnego jako wyodrębnionej wspólnoty. Badania na temat domu inicjowane w obszarze pedagogiki dotyczyły zagadnień

16 J. Izdebska, Dom rodzinny postrzegany przez dzieci w kontekście społeczno-kulturowych zróżnicowań współczesnej rodziny, Białystok 2006.

17 Z. Tyszka, Socjologia rodziny, Warszawa 1978. 
związanych ze zmianami zachodzącymi w domach rodzinnych wskutek dokonujących się przemian społecznych, kulturowych, gospodarczych czy politycznych. Uwzględniają one zatem kontekst bezrobocia i ubożenia polskich rodzin, dezorganizację struktury wewnętrznej spowodowanej czasową niepełnością rodziny związaną z wyjazdem rodzica za granicę, a także przejawy zachowań destrukcyjnych (np. nadużywanie alkoholu) i patologicznych (np. przemoc fizyczna, psychiczna, ekonomiczna, krzywdzenie dzieci) ${ }^{18}$.

Zdecydowanie odmienny obraz domu rodzinnego znamienny jest w sytuacji doświadczania żałoby po zmarłej bliskiej osobie. Śmierć członka rodziny powoduje bowiem daleko sięgające konsekwencje w sytuacji ekonomiczno-bytowej, zmiany w organizacji życia rodzinnego oraz funkcjach realizowanych przez rodzinę. Symptomatyczna zdaje się być ponadto dezorganizacja wewnątrzrodzinnych relacji oraz stosunków z otoczeniem, czyniąc dom rodzinny nie zawsze otwartym na potrzeby i oczekiwania wszystkich jego członków. Dostrzega się w rodzinach osieroconych wiele napięć, obciążeń i stanów lękowych, będących bezpośrednią lub pośrednią konsekwencję utraty osoby bliskiej, rozpadu rodziny, braku kontaktów towarzyskich.

O śmierci osoby bliskiej oraz związanym nierozłącznie z nią bólu, cierpieniu, rozpaczy, doświadczanym niepokoju, można mówić zarówno w aspekcie medyczno-biologicznym, filozoficznym, religijnym, ałe też psychologicznym i pedagogicznym odnoszącym się w sposób szczególny do problemów samotności i osamotnienia człowieka. Trudno jest stworzyć szczególnie precyzyjne pozamedyczne wyjaśnienie pojęcia śmierci. Jest ona nieprzewidziana pod względem momentu i sposobu, w jaki przychodzi, niezależna od tego „,czy naszą reakcją na śmierć jest pragnienie i tęsknota, obawa lub lęk, przerażenie albo spokojne oczekiwanie, czy w całym naszym życiu dominuje doznanie znikomości i niestałości, bądź pełni i rozległości istnienia" ${ }^{\prime 19}$. Rozumienie śmierci przez dziecko, w zależności od wieku i stopnia rozwoju poznawczego, znacznie odbiega od sposobów radzenia sobie z nią przez dorosłych. Dzieci starszę rozróżniające pojęcia śmierć i śmiertelność, doświadczają częściej lęku, depresji i objawów somatycznych niż

18 Zob. J. Rembowski, Rodzina w świetle psychologii, Warszawa 1986; M. BraunGałkowska, Psychologia domowa. Matżeństwo - dzieci - rodzina, Olsztyn 1990; J. Izdebska, Dom rodzinny postrzegany przez dzieci... dz. cyt.; B. Dymara, Dom rodzinny w literaturze $i$ w życiu dziecka, w: Dziecko w świecie rodziny, red. B. Dymara, Kraków 1998; L. Dyczewski, Kultura dnia codziennego i świątecznego w rodzinie, w: Więź między pokoleniami w rodzinie, red. L. Dyczewski, Lublin 2002.

19 M. Scheler, Cierpienie, śmierć, dalsze życie: pisma wybrane, tłum. A. Węgrzecki, Warszawa 1994, s. 89. 
w wieku młodszym. W okresie ciężkiej straty; ich brak doświadczenia i nie w pełni rozwinięta osobowość mogą łatwo spowodować dezorientację i fałszywą ocenę zdarzeń. Dzieci, które osiągnęły umiejętność operowania konkretami, bardziej rozumieją fakt śmierci, będące zaś w stadium operowania formalnego również stan ostateczności i jego nieodwracalność ${ }^{20}$. Podobnie zróżnicowane i skomplikowane są przeżycia osób w czasie żałoby, mają one charakter indywidualny, determinowany tym kogo, kiedy, w jakich okolicznościach tracimy. Odczuwanie krzywdy zależy zatem od wielu czynników, m.in. określonego cyklu życia rodziny (sytuacji, gdy dzieci są dorosłe lub jeszcze nie usamodzielnione), przyczyn śmierci (nagła, w wyniku długotrwałej choroby), otwartości systemu rodzinnego (zdolności do komunikowania myśli i odczuć, umiejętności korzystania z systemu wsparcia społecznego), a także pozycji zmarłej osoby w rodzinie (wypełnianych przez nią funkcji, więzi emocjonalnych pomiędzy zmarłym a poszczególnymi członkami rodziny $)^{21}$. Warte podkreślenia w tym okresie są relacje między żyjącymi bliskimi sobie osobami, bowiem układ więzi wewnętrznych nacechowanych bliskością, serdecznością, bezpośredniością, intymnością i wewnętrzną spójnością stanowi fundamentalny warunek kształtowania się równowagi psychicznej wszystkich członków rodziny ${ }^{22}$.

Określenie wyraźnych granic czasowych życia w żałobie zdaje się być zadaniem niemożliwym do wykonania. Niektórzy badacze twierdzą jednak, że faza uwalniania się od starych przyzwyczajeń i ustalonego porządku trwa około 8 tygodni, całkowitego zaś przystosowania się do nowych warunków pojawia się w okresie ponad dwóch lat od śmierci ${ }^{23}$. W doświadczaniu smutku po stracie wyróżnia się cztery zasadnicze stadia: otępienie po śmierci bliskiej osoby, tęsknotę i żal, dezorganizację i rozpacz z brakiem wizji na zmianę swojej sytuacji oraz reorganizację, w której następuje powolna akceptacja samotnego życia ${ }^{24}$. Analogicznie trudno jest określić ramy czasowe występowania poczucia osamotnienia, m.in. ze

20 R. K. James, B. E. Gilliland, Strategie interwencji kryzysowej. Pomoc psychologiczna poprzedzająca terapię, tłum. A. Bidziński, K. Mazurek,. Warszawa 2005, s. 524

21 K. Krupa, Gdy umiera jedno z rodziców, w: Samotne matki, samotni ojcowie. O rodzinach niepetnych $w$ Polsce, red. D. Graniewska, K. Krupa, J. Balcerzak-Paradowska, Warszawa 1986, s. 106-142.

22 Z. Tyszka, A. Wachowicz, Podstawowe pojęcia i zagadnienia socjologii rodziny, Poznań 1997, s. 46.

23 N. O’Connor, Pożegnanie miłości. Jak przetrwać stratę ukochanej osoby, tłum. M. Duchińska, Warszawa 1994, s. 27-40.

24 M. Herbert, Żałoba $w$ rodzinie. Jak pomóc cierpiacym dzieciom i ich rodzinom, tłum. M. Gajdzińska, Gdańsk 2005, s. 35-38. 
względu na różne jego rodzaje - częściowe, całkowite, pierwotne, wtórne, osobowościowe, sytuacyjne, dłuższe (chroniczne), chwilowe (przemijające), psychiczne, fizyczne (czasowo-przestrzenne), emocjonalne - ale też przyczyny i źródła. Okres żałoby może przebiegać względnie ,,prawidłowo”, albo wykazywać cechy „,patologiczne", związane z zahamowaniem reakcji emocjonalnych lub przerwaniem niezakończonego procesu osierocania ${ }^{25}$. Żałoba wpływa pośrednio na stan zdrowia osób osieroconych, powoduje uaktywnienie lub zaostrzenie wielorakich procesów chorobowych, ${ }^{26}$ przyczynia się do nadużywania alkoholu lub innych środków psychoaktywnych ${ }^{27}$. W jej przebiegu pojawić się może także reaktywna depresja, potwierdzona w tym okresie u około $20 \%$ osób $^{28}$. E. Lindemann w sytuacji żałoby i osierocenia wskazuje na powstawanie różnych zniekształconych reakcji, takich jak: a) nadmierna aktywność, b) nabywanie symptomów choroby, która była przyczyną śmierci bliskiego członka rodziny, c) okazywanie wrogości wobec osób ze swojego otoczenia lub wobec osoby zmarłej, d) nieumiejętność podejmowania działań ukierunkowanych, e) nieświadome karanie siebie (poprzez angażowanie się w sytuacje o przewidywanym niepomyślnym przebiegu lub rezygnację z ważnych dla siebie działań $)^{29}$. Przeżywanie okresu żałoby w rodzinie ma swoją dynamikę. W pierwszej fazie następuje wyraźna konsolidacja sił w rodzinie, wszyscy jej członkowie trzymają się razem, okazują wzajemne wsparcie, dzielą się uczuciami. Gdy ból nie ustępuje, relacje te zaczynają słabnąć, a osieroceni postrzegając często siebie jako niezdolnych do zaoferowania pomocy mogą unikać rozmów z bliskimi, izolować się, nie oczekiwać i nie stosować pozytywnych wzmocnień ${ }^{30}$.

Problematyka osamotnienia wpisuje się w nurt pedagogiki humanistycznej, ułatwiającej rozpoznawanie i nadawanie sensu rzeczywistości, w której funkcjonują rodziny osierocone. W jej założeniu znamienne jest odrzucenie dualizmu podmiotu poznającego i przedmiotu poznawanego, a skupienie się na możliwości

25 K. de Walden-Gałuszko, U kresu. Opieka psychopaliatywna, czyli jak pomóc choremu, rodzinie i personelowi medycznemu środkami psychologicznymi, Gdańsk 1996.

26 H. I. Kaplan, B. J. Sadock, Psychiatria kliniczna, tłum. G. Bagiński, Wrocław 1995.

27 B. Boćwińska-Kiluk, Trudności w przeżywaniu żałoby przez osoby uzależnione od alkoholu, „Nowiny Psychologiczne” 2002, nr 3, s. 63-68.

28 M. Janecki, J. Pyszkowska, J. Janecka, Potrzeby rodziny chorego w okresie terminalnym, w: Rodzina: opieka nad chorym, red. L. Niebrój, M. Kosińska, Katowice 2003, s. $147-152$.

29 Za: K. Sulak, Przyczyny oskarżeń o przemoc wobec osób chorych i zaburzonych psychicznie, „Psychiatria w Praktyce Ogólnolekarskiej” 2002, nr 4, s. 273-276.

30 S. Gross-Wiezmann, P. Kamm, About Mourning - Support and Guidance for the Bereaved, New York 1987. 
przeżywania, doświadczania świata, bycia w nim, myślenia o nim i rozumienia go przez konkretnego człowieka ${ }^{31}$. Wykrycie i uchwycenie związków pomiędzy śmiercią małżonka/rodzica a innymi zdarzeniami w biografii rodzin osieroconych stanowiło asumpt do podjęcia przeze mnie badań na temat fragmentu ich rodzinnego życia, tj. poczucia osamotnienia.

\section{Założenia badawcze}

Przedmiotem podjętych badań jest poczucie osamotnienia spowodowane śmiercią rodzica i małżonka, która nastąpiła wskutek długotrwałej choroby. Celem badawczym było wskazanie źródeł i czynników wywołujących osamotnienie, a także określenie wpływu choroby i śmierci na zachowanie dziecka oraz funkcjonowanie całego środowiska rodzinnego. Sformułowano następujące problemy badawcze: $\mathrm{W}$ jaki sposób śmierć małżonka/rodzica przyczynia się do zmiany sytuacji życiowej rodziny w wymiarze materialnym i emocjonalnym? Jakie czynniki wewnątrzrodzinne kształtują poczucie osamotnienia $\mathrm{w}$ rodzinie osieroconej? Jakie są rodzinne sposoby radzenia sobie $\mathrm{z}$ utratą bliskiej osoby? Badania zostały przygotowane zgodnie z metodologią prowadzenia badań jakościowych w naukach społecznych ${ }^{32}$. Wykorzystano metodę indywidualnych przypadków, technikę wywiadu skategoryzowanego przeprowadzonego $\mathrm{z}$ rodzicem $\mathrm{w}$ zakresie sytuacji rodzinnej i odczuwanej straty oraz wywiadu narracyjnego z rodzicem na temat poczucia osamotnienia $\mathrm{w}$ rodzinie ${ }^{33}$. W badaniach, prowadzonych $w$ ramach seminarium magisterskiego pod moim kierunkiem naukowym, zastosowano celowy dobór próby - wyselekcjonowano dziesięć rodzin zamieszkujących na terenie miasta Białystok, w których jedno z rodziców zmarło w okresie ostatnich dwóch lat z powodu przewlekłej choroby. W eksploracjach uczestniczyło sześć kobiet i czterech mężczyzn w wieku od 25 do 43 lat, spośród których 6 osób legitymowało się wykształceniem wyższym, a 4 średnim. Pięć kobiet i dwóch mężczyzn posiadało jedno dziecko, w dwóch rodzinach wychowywało się troje, w jednej zaś - dwoje dzieci. Najmłodsze dziecko w momencie badań ukończyło lat siedem, natomiast najstarsze było w wieku lat 14 . Procedura badawcza, która przyjęłam

31 M. Nowak-Dziemianowicz, Doświadczenia rodzinne $w$ narracjach. Interpretacja sensów i znaczeń, Wrocław 2006.

32 D. Kubinowski, Jakościowe badania pedagogiczne. Filozofia-Metodyka-Ewaluacja, Lublin 2011.

33 Poczucia osamotnienia z perspektywy dziecka przedstawiono w: J. Szymanowska, A child in the face of a parent's death: Aspects of children's loneliness, „Progress in Health Sciences" 2014, nr 4(1). 
w pracy, zawiera się w nurcie fenomenologiczno-hermeneutycznym. Poszanowanie godności rozmówcy, otwartość, wyrażanie milczącej aprobaty wobec opinii czy przekonań badanych, powodowały, że przeprowadzane wywiady przyjmowały charakter spotkania. Takie podejście umożliwiało dotarcie do przeżyć, doznań i odczuć badanych, spoglądanie na poddawany analizie problem ich oczami, z ich punktu widzenia.

\section{Funkcjonowanie rodziny osieroconej i obraz domu rodzinnego z perspektywy badanych}

Sytuacja ekonomiczno-bytowa badanych rodzin okazała się być na poziomie przeciętnym. Zdaniem badanych śmierć współmałżonka nie wpłynęła znacząco na obniżenie ich statusu materialnego. W każdym środowisku wykazano dochód stały w postaci wynagrodzenia za pracę rodzica i osób wspólnie gospodarujących (dziadków, rodzeństwa rodziców, partnerów) oraz otrzymywanych świadczeń $\mathrm{w}$ ramach zabezpieczenia społecznego z tytułu wystąpienia ryzyka socjalnego, tj. śmierci żywiciela rodziny. Środki pozostające w dyspozycji rodziny pozwalają, zdaniem badanych, na zaspokajanie podstawowych potrzeb wszystkich jej członków, w tym realizację niektórych pragnień indywidualnych.

Dokonując analizy uzyskanych wyników, można stwierdzić, że młodsze dzieci znacznie łatwiej radzą sobie ze śmiercią rodzica niż opiekujący się nimi rodzice i starsze rodzeństwo.

„Nie ukrywaliśmy choroby żony przed synem. Kacper od poczatku wiedziat, że mama jest bardzo chora, ale nie wiedziat doktadnie, co to jest za choroba. Nie wiedziat o konsekwencjach z niq zwiazanych. On miat tylko 9 lat, gdy Ewka zmarta. Gdy Ewa już tak naprawdę umierała, powiedziałem Kacprowi, że mama już bardzo źle się czuje i niedtugo już nas opuści. No jakoś tak to byto, już nie jestem w stanie dokładnie powtórzyć. Syn w miarę spokojnie przyjąt śmierć Ewy. Gorzej byto ze mna" (Daniel, lat 43).

„Śmierć żony najspokojniej przyjąt, przynajmniej tak mi się wydaje, Piotruś. Każde z dzieci przeżywało odejście mamy w inny sposób. Najmłodszy syn często budzit się w nocy z krzykiem: nie oddam mojej mamusi! Szlochat i plakat tak, że nie można go byto uspokoić. Ale tak naprawde to nie rozumiat, co to znaczy, że mama umarła. Byt zbyt malutki. Starszy syn Maciek często mnie natomiast pytał, kiedy pojedziemy do mamusi do szpitala. Gdy dowiedziat się, że mama umarła, wybucht płaczem, uciekt do swojego pokoju i schowat się pod tóżko. Maciek mocno tęsknit i tęskni za mama. Ja tak naprawdę nie potrafitem powiedzieć swoim dzieciom, że ich mama umarta. Nawet Pani sobie nie wyobraża, jakie to jest ciężkie dla ojca. Jednak to, w jaki sposób dowiedziała się o śmierci najstarsza córka 
Gosia - przechodzi ludzkie pojęcie. Lekarz, który prowadzit żonę, nie patrząc w ogóle, że córka jest przy mnie, podszedt i powiedziat: Panie Edwardzie, bardzo mi przykro, zgon nastapit o 13.16. Jak tak można? To my z żona staraliśmy się unikać takich zwrotów, jak śmierć czy zgon, a on tak bezpośrednio... Nawet moja żona, gdy była bardzo słaba, wręcz nieprzytomna, nigdy nie mówiła, że chce już umrzeć, ale że chce już iść do aniołków..." (Edward, lat 39).

„Maż się nie poddawat. Jednak oboje wiedzieliśmy, że jest bardzo źle, bo badania, które musiat systematycznie robić, byly coraz gorsze. Mariusz bardzo cierpiat, a ja razem z nim. W ostatnich jego dniach wolałam, żeby Klaudia go nie widziała. Wyglądat bardzo źle, a chciałam, żeby go zapamiętała jak najlepiej. Nawet w dniu jego śmierci córka równiez nie miała z nim kontaktu. Nigdy nie zapomnę tego ostatniego momentu. Wiedziałam, że stan Mariusza jest już na tyle zły, że jest to kwestia kilku godzin, może dnia... (...) Gdy wróciłam od męża ze szpitala, wziętam Klaudię na kolana i powiedziałam jej, że tatuś właśnie umart, że teraz zostałyśmy dwie i musimy się bardzo kochać. Klaudia o nic nie pytała oprócz tego, dlaczego płaczę. Juz nawet nie pamiętam, co jej wtedy odpowiedziałam. Córka była na pogrzebie. W kaplicy podchodzita do taty, nie zdawata sobie sprawy z tego, co się dzieje" (Agnieszka, lat 41).

„Pomimo tego, że córka wiedziała, jak ciężko chora jest Iza, wiadomość o jej śmierci byta dla niej szokiem. Patrycja prawie przez dwa tygodnie nie chodziła do szkoty. Nawet nie można sobie wyobrazić, jak jej brakowało i nadal brakuje mamy. Na pogrzebie głowę trzymała schylona $w$ dól, nie chciała na nikogo patrzeć albo wstydzita się pokazać łzy. Patrycja nie mogła odnaleźć się w nowej dla nas sytuacji. Ciagle myślała o Izie. Widziałem jak bardzo jest przybita. Przez pierwsze dni po pogrzebie zasypiała w naszej sypialni" (Marek, lat 41).

„Ania od trzeciego roku życia wychowuje się bez mamy. Dlatego też nie przeżywa jej braku tak, jak starsza córka. Dopiero od niedawna zaczęta pytać, gdzie jest jej mamusia i dlaczego nie przychodzi po nia do przedszkola" (Krzysztof, lat 41).

Inny ważny wyznacznik poczucia emocjonalnej próżni związanej z przeżywaniem żałoby wynika ze stanu i jakości relacji wewnątrzrodzinnych. W większości badanych rodzin określone one zostały jako właściwe lub poprawne.

„Staram się jak najwięcej czasu spędzać z córka. Być dla niej matka i ojcem. Ona ma dopiero dziesięć lat, ale czasem wydaje mi się, że jest dzielniejsza ode mnie" (Agnieszka, lat 41).

„Mój maż zmarl trzy lata temu w zimie, miat 39 lat. Zostałam sama z trójka dzieci na głowie. Boże, ile spadło na mnie wszystkich obowiązów, zarówno tych, które wykonuje każda matka, ale i takich, które należa do mężczyzny. Naprawde byt to trudny i ciężki okres $w$ naszym życiu, który musieliśsmy dzielnie przejść. (...) Miałam silna depresję. Całymi dniami mogłam leżeć w tóżku i płakać. W ręce 
trzymałam ramkę ze zdjęciem Leszka. Najmłodsza córkę dziadkowie zabrali na chwile do siebie. Bardzo mi pomogli, gdyby nie oni, nie wiem, co by byto. Ale tego, co zrobit Piotruś, nigdy nie zapomnę. Robił zakupy, pilnowat lekcji Martyni a jednocześnie nie zaniedbat swoich obowiązków szkolnych. To straszne, ale wtedy nic mnie nie interesowato. Dzieci próbowaty ze mna rozmawiać, prosity żebym poszła do lekarza, mówity, że tylko ja im zostałam, ale do mnie nic nie docierało. (...) To syn mi pomógt przejść przez tę tragedię. To on zmobilizowat mnie do walki o nasza rodzinę i pójścia na terapię. Zauważyłam, jakim dojrzałym chtopcem stat się Piotrek" (Katarzyna, lat 42).

Jedynie jedna z uczestniczących w badaniach osób wyraziła ubolewanie, omawiając jakość atmosfery życia rodzinnego (,_Często czuję, że Maciek ma do mnie taki olbrzymi żal, że Monika umarta" - Edward lat 39). W trakcie rozmów badani niejednokrotnie ujawniali rodzaj i siłę więzi łączących ich oraz dzieci ze zmarłym rodzicem i małżonkiem. Zwracali uwagę także na relacje z innymi osobami znaczącymi - dziadkami, rodzeństwem, dalszymi krewnymi.

„Kontakt Roberta z tata byt świetny. Tomek mnóstwo czasu spędzał z naszym synem. Rozpieszczał go. O pomoc, czy z jakimś problemem, Robert nie przychodzit do mnie. Zawsze szedt do taty" (Dagmara, lat 30).

„, Syn przez pierwsze dni po pogrzebie zasypiał tyko w tóżku ze starsza siostrą. Nie odstępowat jej na krok, z problemami przychodzit do niej. Tylko ona potrafita go rozweselić, zająć zabawa, umilić mu czas. Maciek i Gosia wspólnie się bawili, a tym samym myślę, wzajemnie wspierali. Nawet Pani sobie nie wyobraża, jaki dumny jestem z Matgosi, że jest taka odpowiedzialna. Pomimo tego, że nie ma z nami już żony, właśnie Gosia jest taka osoba, która mi ja przypomina. Nie tylko jest do niej podobna ... Opiekuje się dzielnie braćmi, a w szczególności Piotrusiem. Dba, aby miat odrobione lekcje" (Edward, lat 39).

„,Martynka miała z tata dużo lepszy kontakt niż ze mna, dlatego tak łatwo potrafili znaleźć wspólny język. Od niedawna moje relacje z nia znacznie się poprawity. Dużo częściej podejmuje ze mna rozmowy o tacie” (Katarzyna, lat 42).

Przyczyną główną dziecięcego osamotnienia w rodzinie własnej była choroba i śmierć matki lub ojca. Cechował je chroniczny silnie odczuwany lęk o utratę drugiego rodzica, agresja, złość, brak poczucia bezpieczeństwa z powodu niemożności odnalezienia się przez dziecko w nowej sytuacji. Analogicznych przeżyć doświadczali także niektórzy badani dorośli.

„Nie wiedziałam, co powiedzieć synowi, gdy jego tata umart. Nawet nie wiem, co przekazalam i jak. Kiedy Robert dowiedziat się o śmierci taty, stracit poczucie bezpieczeństwa. Stat się bardzo cichy i wycofany. Ta wiadomość, że już nigdy nie zobaczy swojego taty, sprawiła, że całkowicie zamknat się w sobie. Gdy chciatam z nim porozmawiać o tym, co się stało, stawat się bardzo nerwowy, a nawet 
agresywny. Każda próba rozmowy kończyła się awantura i wybuchem złości. On nie pozwalat się nawet do siebie zbliżać, miat pretensje do całego świata. Powiedziatam sobie, że nie moge tak tego zostawić. Nie mogłam pozwolić na to, aby moje dziecko tak cierpiało. Robert wspólnie z tata często chodzili na spacery. Tutaj w pobliżu jest taki lasek, taki maty park. Oni tam bardzo często bywali, ogladali wiewiórki. Gdy znów widziałam rozpacz syna, dtugo nie namyślajac się mówię: "Masz pięć minut, ubieraj się i wychodzimy!» I tak zabrałam go do tego lasu i powiedziałam mu: «Stuchaj, nie jesteś już małym chłopcem i jeżeli ze mna teraz nie porozmawiasz, nie wrócimy do domu, dopóki szczerze nie porozmawiamy». Miałam ze soba zdjęcie męża i zapytałam: «Jak myślisz, czy tata jest teraz szczęśliwy, widzac, jak ty się zachowujesz?» I to byt chyba taki przełomowy moment. Robert bardzo się rozplakat, mocno się do mnie przytulit i nie wypuszczat z objęć. Dlugo ze soba wtedy rozmawialiśmy. Jedno, co utkwiło mi w pamięci, to stowa Roberta, jak jest zly na Pana Boga, że zabrat mu tatę, że on się bardzo boi, że mnie Pan Bóg też weźmie do taty. Przez dłuższy moment nie wiedziałam, co mam mu odpowiedzieć, nie wiedziałam, jak zareagować. Powiedziatam wtedy tylko, że to nie jest ani Pana Boga, ani nasza wina, że taty już z nami nie ma" (Dagmara, lat 30).

„Dlaczego ta paskudna choroba ja spotkała, czym sobie na to zastużyła? Moja żona nie potrafiła tego przyjać i zrozumieć. Szczerze powiedziawszy, ona nie walczyła o siebie. Byłem taki zły na nia, że nie chciała o siebie i o nas walczyć. Zawsze byta taka silna kobieta, a tak szybko się poddała. Najgorsze byto to, że ja w tym wszystkim bytem taki bezradny. Strasznie chciatem jej pomóc, ulzyć w tym całym cierpieniu i bólu, dążyć do lepszego leczenia, częstszych badań i konsultacji. Byto nam wszystkim bardzo ciężko, a najtrudniej wtedy, gdy Monika była już w tak ciężkim stanie, że musiała przyjmować morfinę" (Edward, lat 39).

,Myślałam, że z każdym miesiacem Damian będzie funkcjonowat coraz lepiej, ale byto tylko gorzej. Syn nie chce się uczyć, najchętniej zamyka się w swoim pokoju i czas spędza przed komputerem. Nie spotyka się z kolegami. Jeżeli wychodzi $z$ domu, to tylko do sklepu lub szkoty. Syn stat się smutny $i$ wystraszony. Nie chce rozmawiać o tym, co czuje, często płacze w swoim pokoju. Próbuję z nim rozmawiać o tym, co się stato, jednak on chyba nie jest jeszcze na to gotowy. Któregoś razu powiedziat mi, że tato nas wcale nie kochat, bo jakby kochat, to by nie umart i mieszkat razem $w$ domu, a nie w niebie" (Karolina, lat 36).

„Przed śmiercia męża Tomek byt chłopcem bardzo spokojnym, opanowanym, otwartym na kontakty z innymi osobami. W sumie byt naszym oczkiem w głowie, bo mieliśmy tylko jego. (...) Gdy Kamil zmart, syn zmienit sięo $36 \theta_{\text {stopni. Wcześniej }}$ nie byto z nim większych problemów, choć czasem pojawiaty się niewielkie, jak w każdej rodzinie. Po śmierci męża Tomek stat się bardzo agresywny. Zdarzyto się, ż kilka razy pchną mnie lub oplut. Mówit, że mnie nie kocha, a nawet nienawidzi. 
Jednak najbardziej utkwiło mi w pamięci, jak powiedziat, że lepiej by byto, jakbym to ja umarta. Ja wiem, że w glębi serca on tak wcale nie myśli. Przecież tak mówi sie w chwilach nerwowych, pod wptywem emocji i tęsknoty. Jakby tego byto mało, zaczęly się problemy w szkole. Nie chciat się uczyć, ciagle nie uważat na lekcjach, kilka razy wychowawczyni wzywata mnie do szkoty" (Zofia, lat 37).

Jak wynika z podjętych badań, najczęściej poczucie osamotnienia dziecięcego ujawnia się w nadmiernym pytaniu o zmarłego, płaczliwości, smutku, przygaszeniu, zamknięciu w sobie oraz unikaniu rozmów i kontaktów z innymi osobami.

„Dopiero po jakimś czasie od śmierci żony, syn stat się bardzo smutny. Czas spędzal głównie przed telewizorem. Moja teściowa dużo z nim rozmawiata o Ewie, znacznie więcej niż ja, w dużej mierze dlatego, że batem się pytań, jakie on mi może zadawać. Ciężko patrzy się na swoje dziecko, kiedy jest smutne. Widze jak Kacper przeżywa, gdy np. w szkole obchodza uroczystość Dnia Mamy. Ja zawsze staram się sam iść wtedy do szkoty, ale jednak to nie jest to samo" (Daniel, lat 43).

Pojawienie się choroby w badanych rodzinach oraz związanych z nią trudności stanowiło niewątpliwie czynnik zagrażający sprawnemu funkcjonowaniu całego systemu rodzinnego. Wszystkie dzieci, bez względu na wiek, towarzyszyły rodzicowi w chorobie i przeżywały ją w sposób indywidualny. Interesowały się potrzebami chorych, zazwyczaj pocieszały ich, odwiedzały w trakcie pobytu w szpitalu lub hospicjum, dzieliły się radościami i napotykanymi przeciwnościami.

„Kacper codziennie odwiedzat mamę w hospicjum. Raz tylko była dtu̇̇sza przerwa, gdy wystaliśmy syna na ferie zimowe. Byt to pomyst mojej żony, by Kacpra oderwać od tej smutnej codzienności i widoku cierpienia" (Daniel, lat 43).

„Nasza córka Gosia jako 14-letnia dziewczynka wiedziała od samego poczatku o chorobie mamy. Wspólnie z żona wyjaśniliśmy córce, że jest groźna i jakie moga być jej konsekwencje. Gosia chętnie chodziła ze mna do Moniki do szpitala. Byty momenty, gdy widziatem, że chca ze soba porozmawiać o babskich sprawach. Wychodzitem wtedy z sali i zostawiatem je same" (Edward, lat 39).

„W trakcie choroby Paulina bardzo pomagała mamie. Troszczyła się o nia, często mówiła: «Mamusiu może ja zrobię dla ciebie herbatkę malinowa i nie będzie cie już bolało». (...) Najgorsze byto to, gdy żonie brakowało już tchu, żeby mówić. Widziatem jak Paulinka była przerażona. Nie wiedziała, co się dzieje, gdy Marta zaczynała się dusić. Cała trzęsta się ze strachu”" (Krzysztof, lat 41).

Dzieci, przeżywając stratę bliskich, podobnie jak osoby dorosłe, potrzebują okresu smutku i żałoby wypełnionej żalem i rozpaczą. Prawem osób osieroconych jest pozwolenie im na subiektywne intymne doświadczanie śmierci i żałoby oraz związanej z nimi pustki.

„Po pewnym czasie staram się ułożyć życie na nowo. Niedawno zamieszkatem z Anną. Kacper się z nia zaprzyjaźnit, dużo rozmawiaja o jego mamie. Chodze 
z Kacprem na grób Ewy bardzo często. On lubi ją odwiedzać, ale zabrania żeby chodziła z nami Anna. Zauważytem, że Kacprowi brakuje mamy coraz bardziej. Wcześniej syn rzadko płakat, gdy ktoś wspominat o mamie. Teraz zdarza się to coraz częściej, nawet, gdy stoi nad grobem Ewy i opowiada jej co się wydarzyło, np. co dzisiaj robił lub co mu kupitem" (Daniel, lat 43).

„Dopiero około 3 miesięcy od śmierci męża Klaudia zaczęła odczuwać jego brak. Dużo rozmawiała ze zmarlym tata. Doskonale pamiętam, gdy pewnego razu po powrocie z pracy zastałam córkę siedzaca na dywanie. Czesała lalkę. Była to taka fajna dziecięca rozmowa: "Tato, ale ty nie umiesz zrobić takiego kucyka jak ja». Często zdarzały się jej takie dialogi, niektóre byly też zabawne. Nie uważałam żeby to było coś złego. Często przychodziła też do mnie i pytała, czy to prawda, że tatuś jest u aniołków. Nie wiem, skąd w jej główce brały się takie pytania. Czy tęskniła za Mariuszem i chciała się upewnić, gdzie on jest, czy w szkole ktoś o niego pytat, czy może liczyla na to, że tato wróci? W sumie nigdy z niq o tym wtedy nie rozmawiałam. Nie potrafitam" (Agnieszka, lat 41).

„Pati ciagle chciała rozmawiać o Izie. Porównywała to, co ja zrobiłem, do tego, jak robiła to Iza. Ona nawet przez długi czas wktadała zawsze po wyjściu spod prysznica szlafrok mamy i używała jej kremu do rak. Do dnia dzisiejszego korzysta z tego samego płynu do kapieli, którego używała żona. Do szkoły często zakłada rzeczy należace do mamy, jakiś tam pasek czy spinkę. Sadzi, że jak będzie coś mieć z jej garderoby, to zawsze będzie o niej pamiętać. Patrycja ma na szyi taka rybkę, która kiedyś nosita Iza. Nawet jak oglada telewizor - to na poduszeczce żony. Czasami śmieję się z niej, że ubrania sq na niq zbyt duże, ale ona i tak je zaktada. Nie było dnia w naszym domu, żeby nie wspominać Izki” (Marek, lat 41).

„Damian na pogrzebie stat caty czas ze mna przy trumnie. Cała mszę w kościele byt dzielny, na cmentarzu tė̇ stał w milczeniu, bardzo spokojnie. Nie zauważyłam u niego nawet łez. Sama załamana musiałam być oparciem dla niego. Damian bardzo tęskni za tata. Każdego dnia czeka, aby mu się przyśnit”" (Karolina, lat 36).

„Pamiętam, jak Martynka nie chciała pójść z nami na grób w rocznicę śmierci Leszka. Wykrzyczała nam, że nas nie kocha i nigdzie nie idzie, pomimo tego, że wszyscy ja prosiliśmy, i ja, i babcie" (Katarzyna, lat 42).

Dla prawidłowego rozwoju rodziny tracącej jednego z członków niezbędne jest możliwie szybkie uruchomienie wsparcia zarówno nieformalnego, jak też formalnego. $\mathrm{Z}$ dziesięciu badanych rodzin, tylko dwie korzystały z konsultacji psychologa i pedagoga szkolnego, pozostałe zaś wyłącznie z pomocy rodzeństwa, krewnych, przyjaciół. Ważne jest, aby dzieci mogły swobodnie wyrażać swoje uczucia, a towarzyszący im dorośli zapewniali poczucie bezpieczeństwa, pomagali uspokoić się oraz zrozumieć zdarzenia, w których uczestniczą. 
„Ja sam nie wiedziatem, co mam dalej robić i co gorsze - nic się nie chciało. Myślałem o tym, że muszę zajać się synem, ale nie bardzo wiedziatem, jak. Bałem się, że za chwile przyjdzie do mnie opieka społeczna i nie dość, że zabrano mi żonę, to jeszcze i on zostanie mi zabrany. Na szczęście moja teściowa zrezygnowata z pracy, by pomóc mi w opiece nad Kacprem. Pomocna rękę wyciagnęła do mnie również Aga, moja szefowa, która namówiła mnie na terapię w poradni psychologicznej. Uważatem, że jest mi to zupetnie niepotrzebne, ale poszedtem ze względu na Kacpra. Nawet na niektóre spotkania zabierałem go ze sobq" (Daniel, lat 43).

„,Już dziś Robert powoli zapomina o wszystkim. Nie, żebym miała na myśli, że zapomina o tacie, bo ja mu nigdy na to nie pozwolę. Ale teraz już chętnie pokazuje zdjęcia męża, dużo o niego pyta i często go wspomina" (Dagmara, lat 30).

„Często widze, jak dzieci ogladaja w salonie na kanapie rodzinne albumy. $W$ domu bardzo często powracamy wspomnieniami do mamy. Dużo opowiadam dzieciom o niej, ale najczęściej i tak rozmawiaja o mamie ze sobq" (Edward, lat 39).

„Dziś Klaudia zadaje mnóstwo pytań o tatę. Ja sama tė już zachęcam ja do rozmów o Mariuszu, bo wiem, że jej to pomaga. I mi samej również. Nie wyobrażam sobie, żeby córka miała o nim zapomnieć, o tym jak wygladat, co robit, jaki byt. Myślę, że dzięki naszym rozmowom, Klaudia potrafi już powiedzieć, że taty nie ma, że jej tata umark. Mówi o tym tak normalnie, pokazuje go na zdjęciach wszystkim odwiedzającym nas gościom" (Agnieszka, lat 41).

„Chodziliśmy z synem do pedagoga w szkole, ale tak naprawdę to nic nie dawało. Nie ma co doszukiwać się przyczyn jego nieprawidłowego zachowania, bo jedyna jest to, że nie ma Kamila. Próbuję z Tomkiem rozmawiać, ale on jest bardzo niechętny. Nie radzi sobie z ta straszna tragedia, jaka nas spotkata. Niechętnie bawi się z kolegami, nawet wychowawczyni zauważyla, że przerwy spędza sam. Chodzę $z$ Tomkiem na spotkania z psychologiem. Na razie nie widzę żadnych rezultatów, ale pani psycholog utwierdza mnie w przekonaniu, że na wszystko trzeba więcej czasu. Ewidentnie widzę, że im jest starszy, tym bardziej brakuje mu ojca i coraz trudniej jest mu pogodzić się z jego śmiercia”" (Zofia, lat 37).

\section{Refleksje końcowe}

Jak wynika z zebranego materiału badawczego, odejście rodzica i współmałżonka jest dla pozostałych członków rodziny wydarzeniem traumatycznym, ale przede wszystkim indywidualnym doznaniem wywołującym wycofanie, niejednokrotnie ucieczkę w świat nierealny. W rodzinach osieroconych dostrzega się zdecydowanie wiele napięć, obciążeń i stanów lękowych, będących bezpośrednią lub pośrednią konsekwencję utraty osoby bliskiej, rozpadu rodziny, braku kontaktów towarzyskich. Jednym z elementów wsparcia udzielanego osobom 
osieroconym powinno być przekazanie informacji na temat przebiegu żałoby i specyficznych doznań emocjonalnych znamiennych na każdym z jej etapów. $\mathrm{Z}$ jednej strony pomaga to zrozumieć sytuację kryzysową, $\mathrm{z}$ drugiej zaś przygotować się do dalszych faz przeżywania straty ${ }^{34}$. Wydaje się, że pomimo wielu starań czynionych przez rodziców i specjalistów w zakresie wzmacniania rodziny w sferze społeczno-emocjonalnej, problem ten jest ciągle istotny, aktualny. Pomoc dziecku i rodzinie, bez względu na podmiot ją realizujący, powinna stwarzać przede wszystkim możliwość wyrażania własnych emocji, refleksji o zmarłym rodzicu czy małżonku, odrzucenia poczucia odpowiedzialności i winy za zaistniałą sytuację. Wśród najważniejszych zadań stojących przed rodziną w żałobie wyróżnia się takie, jak: zrozumienie przerwania osobistych więzi łączących ze zmarłym, redukcję wewnętrznego napięcia spowodowanego stratą, modyfikację niedawnej struktury obowiązków i ról rodzinnych, a także odnalezienie przez osieroconą rodzinę, a w szczególności dziecko, nowych relacji ze światem zewnętrznym ${ }^{35}$.

\section{Literatura}

Boćwińska-Kiluk B., Trudności w przeżywaniu żałoby przez osoby uzależnione od alkoholu, „Nowiny Psychologiczne” 2002, nr 3, s. 63-68.

Braun-Gałkowska M., Psychologia domowa. Matżeństwo - dzieci-rodzina, Olsztyn 1990.

Dyczewski L., Kultura dnia codziennego i świątecznego w rodzinie, w: Więź między pokoleniami w rodzinie, red. L. Dyczewski, Lublin 2002.

Dymara B., Dom rodzinny w literaturze $i$ w życiu dziecka, w: Dziecko w świecie rodziny, red. B. Dymara, Kraków 1998.

Gajda J., Samotność i kultura, IWZW, Warszawa 1987.

Gross-Wiezmann S., Kamm P., About Mourning - Support and Guidance for the Bereaved, Human Sciences Press Inc., New York 1987.

Herbert M., Żałoba w rodzinie. Jak pomóc cierpiacym dzieciom i ich rodzinom, tłum. Monika Gajdzińska, GWP, Gdańsk 2005.

Hołyst B., Na granicy życia i śmierci, PWN, Warszawa 1997.

Izdebska J., Dom rodzinny postrzegany przez dzieci w kontekście społeczno-kulturowych zróżnicowań współczesnej rodziny, Białystok 2006.

Izdebska J., Dziecko osamotnione w rodzinie. Kontekst pedagogiczny, Trans Humana, Białystok 2004.

34 M. Herbert, Żałoba $w$ rodzinie..., dz. cyt.

35 M. Ogryzko-Wiewiórowska, Rodzina i śmierć, Lublin 1994, s. 67-68; Zob. C. M. Parkes, Bereavement: Studies of Grief in Adult Life, London 1972. 
James R. K., Gilliland B. E., Strategie interwencji kryzysowej. Pomoc psychologiczna poprzedzająca terapię, tłum. A. Bidziński, K. Mazurek, Parpamedia, Warszawa 2005.

Janecki M., Pyszkowska J., Janecka J., Potrzeby rodziny chorego w okresie terminalnym, w: Rodzina: opieka nad chorym, red. L. Niebrój, M. Kosińska, ŚAM, Katowice 2003, s. 147-152.

Kaplan H. I., Sadock B. J., Psychiatria kliniczna, tłum. Grzegorz Bagiński, Urban \&Partner, Wrocław 1995.

Kmiecik-Baran K., Poczucie osamotnienia - charakterystyka zjawiska, ,Przegląd Psychologiczny" 1988, t. XXXI, nr 4, s. 1086.

Krupa K., Gdy umiera jedno z rodziców, w: Samotne matki, samotni ojcowie. O rodzinach niepetnych $w$ Polsce, red. D. Graniewska, K. Krupa, J. BalcerzakParadowska, IWZZ, Warszawa 1986.

Kubinowski D., Jakościowe badania pedagogiczne. Filozofia-Metodyka-Ewaluacja, Wyd. UMCS, Lublin 2011.

Łopatkowa M., Samotność dziecka, Czytelnik, Warszawa 1983.

Łuczak E., Szewetowska K., Rozmiary sieroctwa społecznego, „Problemy Opiekuńczo-Wychowawcze" 1997, nr 2.

Mellody P., Facing codependence. What it is, Where it comes from, how it sabotages our lives, Published by Harper, San Francisco 1993.

Nowak-Dziemianowicz M., Doświadczenia rodzinne w narracjach. Interpretacja sensów i znaczeń, Wyd. Naukowe Dolnośląskiej Szkoły Wyższej Edukacji TWP, Wrocław 2006.

O’Connor N., Pożegnanie miłości. Jak przetrwać stratę ukochanej osoby, tłum. Małgorzata Duchińska, Jacek Santorski \& CO Agencja Wydawnicza, Warszawa 1994.

Ogryzko-Wiewiórowska M., Rodzina i śmierć, Wyd. UMCS, Lublin 1994, s. 67-68. Olearczyk T. E., Sieroctwo i osamotnienie. Pedagogiczne problemy kryzysu wspótczesnej rodziny, Wyższa Szkoła Filozoficzno-Pedagogiczna „Ignatianum”, Kraków 2007.

Parkes C. M., Bereavement: Studies of Grief in Adult Life, Tavistock Publications, London 1972.

Pawłowska E., Jundziłł E., Pedagogika człowieka samotnego, Wyd. GWSH, Gdańsk 2003.

Perlman D., Peplan L. A., Toward a social psychology of loneliness, w: Personal relationships in disorder, red. S.W. Duck, R. Gilmour, Academic Press, London 1981.

Rembowski J., Rodzina w świetle psychologii, Warszawa 1986.

Rembowski J., Samotność, Wyd. UG, Gdańsk 1992. 
Scheler M., Cierpienie, śmierć, dalsze życie: pisma wybrane, tłum. Adam Węgrzecki, PWN, Warszawa 1994.

Sulak K., Przyczyny oskarżeń o przemoc wobec osób chorych i zaburzonych psychicznie, „Psychiatria w Praktyce Ogólnolekarskiej” 2002, nr 4, s. 273-276.

Szczepański J., Sprawy ludzkie, Czytelnik, Warszawa 1978.

Szymanowska J., A child in the face of a parent's death: Aspects of children's loneliness, „Progress in Health Sciences” 2014, nr 4(1).

Szymborska A., Sieroctwo społeczne, Wiedza Powszechna, Warszawa 1969.

Szyszkowska M., Ucieczki w samotność i osamotnienia, w: Samotność i osamotnienie, red. M. Szyszkowska, IWZW, Warszawa 1988.

Tyszka Z., Socjologia rodziny, Warszawa 1978.

Tyszka Z., Wachowicz A., Podstawowe pojęcia i zagadnienia socjologii rodziny, Wyd. Akademii Rolniczej im. Augusta Cieszkowskiego, Poznań 1997.

Walden-Gałuszko K. de, U kresu. Opieka psychopaliatywna, czyli jak pomóc choremu, rodzinie i personelowi medycznemu środkami psychologicznymi, Wyd. MAKmed, Gdańsk 1996.

Young J. E., Loneliness, depression and cognitive therapy: Theory and application, w: Loneliness: A sourcebook of current theory, research and therapy, red. L. A. Peplan, D. Perlman, New York 1982.

\section{Joanna Szymanowska: „Our home is not the same any more” - the feeling of loneliness in bereaved families}

The subject of the research was the loneliness in families caused by the death of a parent/ spouse resulting from a long-standing illness. Ten families (6 mothers, 4 fathers, 15 children) from the city of Białystok, who had been during the mourning period for 2 years, were included in the qualitative research. The case study method was applied, as well as the following research techniques: structured interview and narrative interview.

Key words: solitude and loneliness, family home, functioning of bereaved families. 